\title{
Russian liberal thought and the formation of the modern theory of political parties
}

\author{
Igor Andreev ${ }^{1, *}$ \\ ${ }^{1}$ National research Moscow State University of Civil Engineering, 26, Yaroslavskoye shosse, 129337, \\ Moscow, Russia
}

\begin{abstract}
The report highlights the little-explored aspects of the Russian liberal theory of political parties in the second half of the XIX - 30s of the XX centuries: the stages of its development, the philosophical foundations, and the innovative ideas of its main representatives. Analyzing the works of Russian liberal thinkers, the author used the methods of philosophical research, as well as approaches used in historical and political sciences, and also general scientific methods, such as logical and classification methods. The author distinguishes three stages in the development of the Russian liberal theory of political parties in this period: 1) 1858-1889; 2) 1889-1917); 3) 1917-1930s, which differ by subject of study (Russian or Western parties) and research tasks (preparing the conditions for the transition from authoritarianism to democracy or fighting against the totalitarian Communist system). The author notes the heterogeneity of the philosophical foundations of the Russian liberal theory of political parties, which included neo-Hegelianism, positivism, and even elements of Marxism. Among the most important achievements of Russian liberals, the author notes the study of the social nature and functions of party elites (Ostrogorski) and determining the place and role of the ruling parties in authoritarian and totalitarian political systems (Chicherin, Miliukov).
\end{abstract}

\section{Introduction}

The Russian political thought made a substantial contribution into the formation and development of the international theory of political parties. Russian liberal thinkers played a significant role in this process. M.Ya. Ostrogorski, a Russian liberal thinker, whose research was focused on the party systems of the USA and UK, is recognized, along with R. Michels (and sometimes with J. Bryce) as the founder of the international theory of political parties. The ideas, expressed by such liberal theorists, as B.N. Chicherin, P.N. Milyukov, M.M. Kovalevsky, Yu.S. Gambarov and A.N. Rykachev also enjoy high assessments.

The author found valuable material on various aspects of the Russian liberal theory of political parties in works by G.M. Hamburg [1], P. Pombeni [2], G. Quagliariello [3], M.K. Stockdale [4].

At the same time, many issues related to the topic of this report have not yet received adequate coverage.

\footnotetext{
${ }^{*}$ Corresponding author: andreev-i-v@yandex.ru
} 
In particular, the author has set a goal to achieve further progress in the coverage of the issues in this report:

- social and philosophical bases of the Russian liberal theory of political parties;

- stages of development of the Russian liberal research school of the institute of political parties;

- specific personal contribution of ideologists of the Russian liberalism to the formation and development of the world and national theory of political parties;

- substantiating and defending the priority of the Russian liberal researchers in solving certain problems of the theory of political parties.

The relevance of this topic is evidenced by the phenomenon of using the ideological heritage of the old Russian liberals in the modern domestic practice of building and functioning of party structures. This situation increases the importance of adequate interpretation and perception of the liberal heritage.

\section{Methods}

The «junctural» nature of our topic led to the complex use of methods of philosophical research, as well as the approaches used in the historical and political sciences. Besides, we also used here general scientific methods, such as logical and classification methods.

The source base of the research is primarily the monographs and articles by the representatives of the Russian liberal political thought, which directly or along with other issues addressed the problems of the institute of political parties.

\section{Results}

\subsection{B. Chicherin}

B.N. Chicherin was the founder of the Russian liberal school of political parties back in the 50ies of the $19^{\text {th }}$ century. The main strength of his research consists in his «building a bridge» between the early theory of political parties and its present-day counterpart. $\mathrm{He}$ attained remarkable results in the research into «early» West European political parties and drew attention to the fact that they had been ousted from the political arena by mass parties.

Boris Chicherin in his papers «Essays of England and France» (1858) and «About national representation» (1866) for the first time in the Russian political theory opened and solved such problems as the comparative characteristic of party systems; basic typology of the Western European ideological and political trends; social-class determinants of a parthenogenesis (in particular, ascertaining of cause-effect dependence between growth of middle classes parliamentary representation in Great Britain and lowering of discipline in parliamentary fraction of liberals).

Another distinguishing feature of B.N. Chicherin's works consists in the central position, occupied by the Hegelian dialectic in the set of his methodological tools. His «conservative» interpretation of the Hegel's system and method pre-determined his commitment to finding an instrument for a crisis-free and reform-oriented societal development, for something uniting the social groups instead of separating them. In practice, party elites are made responsible for the implementation of party policies. According to B.N. Chicherin, their inability to assume this responsibility may set the stage for a severe crisis within the society and its political system, which may destroy the entire system of «regular» public relations. 
Boris Chicherin substantiated the need for political parties («directions») both from the perspective of philosophy and sociology.

Concerning philosophy, he deduced the conditionality of this social institution primarily from the Hegelian concept of separation and «philosophical distinction» of civil society and the state, considering their relationship from the perspective of unity and the struggle of opposites. If the main characteristic of the state is «unity», Chicherin believed, then civil society is characterized by "social discord», and interestingly these phenomena are in the relationship of correspondence and mutual completion. And since parties are an integral component of civil society, their most common features are derived from its «nature», from the laws of the functioning and development of the social system.

According to Chicherin, the laws of the functioning of society imply the recognition of the structural complexity of the social organism, the presence in it of a certain set of interacting components-social communities («categories of persons»), seeking to realize their interests and to implement them with the help of state power. An attempt to ignore or block the expression of these interests, Chicherin warned, is fraught with destructive consequences for society.

The laws of development of society presuppose a dialectical interaction of «moments» of change and «preservation of the acquired», which in the sphere of political consciousness and political practice is expressed in the competition of «elements of two kinds: protective and progressive».

For a deeper philosophical elaboration of the place and role of the institution of political parties in society, Chicherin also turns to the traditional socio-philosophical problem of the relationship between civil society and the state; the latter, however, is considered in the context of a broader «political union» (or «political order»), which includes, in addition to state bodies, non-state political structures, in particular, political parties. Thus, Chicherin, gave new life to Locke's approach to the analysis of this range of issues, in which, as we know, the English theorist introduced the concept of «political community» as a broader concept than the concept of «state» and included all kinds of voluntary unions and agreements of people about the choice of their ways of government. As another key pair of concepts, Chicherin used the concepts of «organic» and «inorganic» social connections. By the first of them, he meant a set of purposefully and imperatively regulated social relations, essentially identical to the system of interaction of state bodies. "Inorganic» social relations, by the philosopher's definition, being the supporting structure of the sphere of «freedom», were devoid of these characteristics and included not only the entire sphere of civil society, but also non-state components of the «political union» («political order»), in particular, «the influence of public opinion», the print media, political parties, and «political assemblies» [5]. Schematically, the relationship of the above concepts can be represented as follows.

Table 1. Correlation of the main concepts describing social and political relations in B. Chicherin's philosophy.

\begin{tabular}{|c|c|c|}
\hline \multirow{2}{*}{$\begin{array}{l}\text { «Political } \\
\text { Union» }\end{array}$} & State & Sphere of Organic Social Relations \\
\hline & $\begin{array}{l}\text { Non-State Components of the } \\
\text { «Political Union»: } \\
\text { Parties, Print Media, etc.) }\end{array}$ & \multirow[t]{2}{*}{ Sphere of Inorganic Social Relations } \\
\hline \multicolumn{2}{|c|}{ Civil Society } & \\
\hline
\end{tabular}

The Chicherin's arguments clearly show that he considered the institution of political parties as the highest type of non-state components of the "political union» due to such features inherent in parties and close to the signs of «organic» social relations, as the presence of developed organizational and hierarchical structures, stability, and direct participa- 
tion in the formation of state authorities. In this connection, he also noted the powerful and often decisive influence of parties on the functioning of the print media, public opinion, etc. [5]. Therefore, it would not be entirely accurate to characterize political parties as intermediaries between civil society and the state: in fact, they mediate the relationship between the "organic» and "inorganic» subsystems of the social system; "formally» referring to the latter, the parties seem to «rise» above it, approaching the state in a number of their dimensions and, in fact, being the second most important political institution after it.

We guess, it is exactly the statement of similarity of some most important parameters of the institution of political parties and the state, considered by Chicherin (inspired by the Hegel's ideas) as an embodiment and realization of the moral idea of serving the ideal of the common good, that has largely caused the presence of such a significant normative component in Chicherin's party research: he not only studies parties, but also urges them to emphasize the needs of society as a whole in the course of their activities, to achieve reasonable compromises, and to assimilate the most successful program installations of each other. Certainly, this attitude was also conditioned by Chicherin's «conservative» interpretation of the Hegel system and method in general: in contrast to, for example, K. Marx, Chicherin did not seek to draw «revolutionary» conclusions from the Hegelian dialectic, focusing on the search for the mechanisms of crisis-free, reformist development of society, and seeking for what unites social groups rather than divides them.

The sociological aspect of this issue brought Chicherin to a more specific level of analysis of the relationship between party politics, the degree of development of the party organization and the interests of certain social groups.

It is noteworthy that Chicherin, a principled opponent of Marxism, was very close to the methodological guidelines of Marxist party science in the context of the social nature of political parties, pointing out the connection of party politics with the interests of certain classes. At the same time, the theorist distanced himself from Marxist approaches to the issue of the origin of political parties. B. N. Chicherin believed that this phenomenon is directly related to the significant development of democratic principles of political life, with a serious expansion of the electoral rights of citizens who have received great opportunities to participate in the affairs of the state. As is well known, this approach proved to be the most widespread in the world scientific community, but it faced fierce criticism from Marxist-Leninist social scientists, who deduced the emergence of the institution of mass organized political parties from the aggravation of the class struggle between the proletariat and the bourgeoisie.

Boris Chicherin did not provided the expanded definition of the term «political party», but the signs of this concept in his works look quite modern: an organizational structure, the goal of establishing the state power, the stability of the existence, the presence of ideological and political programs, and the desire to enlist the support of the greatest possible number of citizens.

An important feature of the methodology introduced by Boris Chicherin was the use of some simple elements of functional analysis, through which he tried to determine the main directions of the positive and negative impact of parties on the socio-political sphere and based on this to formulate recommendations for optimizing the activities of this political institution.

Among the key, «essential» functions of political parties, Chicherin referred to such functions as representative (expression of the interests of certain social groups), programideological, organizational, function of recruiting political leaders, conducting parliamentary struggle, and exercising state power. He believed that the implementation of these functions by parties within the limits of a reasonable «measure» could ensure the identification of diverse and rapidly changing social interests, optimize the political participation of the electorate that had significantly expanded by the end of the $19^{\text {th }}$ century in Western 
countries, and increase the efficiency of state power. In particular, not being a supporter of fetishizing the principle of separation of powers, Chicherin considered it very useful for coordinating the actions of the executive and legislative branches of power to ensure that one of the «system» parties controls both the parliament and the government.

Chicherin sought to address the issue of the dysfunctional consequences of the parties' activities dialectically, as inspired by the famous aphorism «our shortcomings are the continuation of our virtues». The essence of the problem, he believed, consisted primarily in the fact that excessive emphasis on the spirit of partisanship led to a diminution in the political sphere of the importance of the interests of society as a whole, and thus to a violation of the fundamental laws of the functioning and development of society. In general philosophical terms, it was thus about the conflicting aspects of the dialectical relationship of the social whole and its parts. Another aspect of this problem was that the implementation of parties' organizational functions leads to the dominance in party structures of «a special class of low politicians that make a craft and a means of profit out of political campaign», causing the erosion of the ideological and political identity of the parties, transforming them from the tools of implementing the interests of certain social class groups to the corporation of party elites engaged in the «theft» of the government property «on a vast scale and in the most shameless manner» [5].

Thus, the Chicherin's analysis of the dialectics of the relationship between functional and dysfunctional consequences of the political parties' activities highlighted two major contradictions, the development of which determines the main direction of party genesis: 1) the contradiction between the private goals of parties and the goals of society as a whole; 2) the contradiction between the political (in the true sense) aspects of party activity and its aspects related to the satisfaction of narrow group interests of party elites.

The optimal political form that could minimize the negative consequences of the political parties' activities was represented to the philosopher as a constitutional parliamentary monarchy, of which he called Great Britain as a model. This form, he believed, surpasses developed democracy in its ability to ensure the «preponderance» of the «educated classes» and to block the «absorption» of social «quality» by the social «quantity». This feature of the constitutional monarchy was directly related to the party system, manifested in the influential role of aristocratic elements within the party elites. Besides, Chicherin considered a significant feature of the British constitutional monarchy to be the monarch's right to influence the formation and functioning of the executive power (even if it is not often exercised), thereby «moderating» the harmful effects of inter-party competition. (Certainly, to use modern terminology, it was an issue of comparing the more democratic political systems of the United States and France with somewhat less democratic political system of the United Kingdom rather than contrasting the «democracy» with a constitutional monarchy) [5].

As we can see, one of the fundamental conditions for optimal, i.e., reformist development of society, Chicherin considered the effective role of a subjective factor, understood as the activity of an enlightened political elite (both involved in party structures and acting outside them) to influence the system of public relations with a dual purpose: first, timely removal of obstacles to the urgent requirements of social progress and, secondly, ensuring the stability of society, necessary for a more or less long-term «assimilation» and consolidation of changes.

The inability of the ruling elite to realize this purpose, Chicherin believed, could create preconditions for a deep crisis of society and the political system, fraught with the threat of destroying the entire system of «normal» social relations. In this regard, Chicherin's characterization of an eventual political system in the third part of the «Course of State Science», which is capable of replacing «traditional» democratic and authoritarian regimes in a situation of such a crisis, is of great interest; in modern political science, this system is des- 
ignated as totalitarian, and Chicherin himself called it an «all-encompassing machine» - a term that is, in essence, a calque of the Latin totalitas, which is something complete or comprehensive [5].

Among the most important characteristics of the radical socialist «all-encompassing machine» Chicherin included as follows:

- undivided dominance of the radical socialist party in the system of power relations;

- the character of the ruling party compared to that of the traditional parties, which differs from them not only in its «non-system» program settings, but also in its highly organized and ideological fanaticism, which makes it more politically competitive;

- forced imposition on society of the ideology of the radical socialist party - an ideology, according to Chicherin, «exclusive and intolerant»;

- the tendency to establish a regime of personal power, which is facilitated by the oneparty nature of the political system;

- elimination of all political and personal rights and freedoms of citizens;

- a massive use of violence, even unprecedented in the history;

- an important role of the broad masses - the social support of radical socialists - is in the functioning of the political system [5].

The attempt to localize the Chicherin concept of the «all- encompassing machine» in the continuum of subsequent representations of totalitarianism shows first of all its proximity to the views of N. A. Berdyaev, P. B. Struve, S. L. Frank, and others, who attributed to this social phenomenon the features of an «ideocracy» - the domination of some abstract universal idea over all aspects of society. At the same time, the model of the political system analyzed by Chicherin was a fundamentally new phenomenon that had no earlier analogues either in the face of ancient despotists or in the face of authoritarian regimes of the middle ages and the modern times. In this regard, the views of the Russian theorist diverged from the approaches of many foreign researchers (K. Wittfogel [6], B.J. Moore-Gilbert [7] et al.), who interpreted totalitarianism as a kind of «reissue» of certain previous undemocratic forms of political organization of society.

The complex of Chicherin's views was in many aspects consonant with the «traditional» interpretations of totalitarianism formulated after the Second World War in the works by H. Arendt [8], K. Friedrich, Z. Brzezinski [9], and others. In particular, the attributes of totalitarianism systematized by K. Friedrich (the «six-point syndrome») are very similar to the characteristics of Chicherin listed above, which, unfortunately, unlike the German researcher, did not consider it necessary to put them in such a «stamped» and lapidary form. Boris Chicherin can be considered as the predecessor of $\mathrm{H}$. Arendt in the formulation of the problem of the interdependence between totalitarian organizations and the structureless human mass, although this thesis, in our opinion, was one of the reasons that caused the crisis of the theory of totalitarianism at the turn of the $20^{\text {th }}-21^{\text {st }}$ centuries. The absolutization by Chicherin and the subsequent researchers of the attribute of «lack of structure» engaged in a totalitarian movement of «mass» hindered the adequate perception due to the development of modern industry process, the structuring and organization of the proletarian layers of the population - a phenomenon which was analyzed by K. Marx in the middle of the $19^{\text {th }}$ century and later became the basis for effective practical and political actions of representatives of both «left» and «right» totalitarian movements.

Considering that Boris Chicherin, unlike all the above-mentioned political scientists, did not have the opportunity to see the functioning of the «all-encompassing machine» in reality, we have to marvel at the scale of his visionary gift, which allowed him to identify several parameters of this social phenomenon, confirmed by much later scientific developments. Although we may not be able to prove the thesis about the direct impact of this system of Chicherin's ideas on subsequent generations of researchers, even domestic ones, he was undoubtedly among the founders of the theory of totalitarianism. 


\subsection{Ostrogorski}

Even while studying at the Free School of Political Science in Paris (1883-1885), Moisey Ostrogorski could not help but note the trend of politicization of constitutional law and the penetration of sociological methods into the sphere of state studies, which marked the emergence of a new scientific discipline in France - political science. At the turn of $19^{\text {th }}$ $20^{\text {th }}$ centuries, the USA was also switching to the study of the political process in relation to social processes and psychological motives of individuals. Ostrogorski has repeatedly focused the attention of his readers on this feature of his methodological tools. Thus, in the introduction to his main work, he noted as the main feature of his research method, the goal of analyzing not the «political forms», but the «driving forces» of the political process. It is also noteworthy that Ostrogorski described his main work not only as a political work, but also as a psychological work. Thus, the scientist set the task of moving from the study of the legal form of political life to the study of its content [10].

The monograph «On the Organization of Political Parties in the United States of America», written in $1888-1889$, became the first large achievement of Ostrogorski. In the monograph based on the analysis of the main tendencies of social and economic development of the USA there were made some conclusions about the reorientation of the main political parties of the USA to service of interests of large business, on splicing of party and state elite. Ostrogorski considered this circumstance, and also the exhaustion of significant political problems in the USA after the end of the Civil War as a principal reason of an erosion of ideological and political identity of the Democratic and Republican parties. From that moment Ostrogorski positioned this phenomenon as the decisive proof of historical exhaustion of institute of political parties and its future disappearance from political life stage. Also the regularity of inner-party development including the complication of parties organization structure formulated by this Russian scientist are of exceptional interest; the centralization management strengthening of parties shown in reduction of a role of national and regular congresses and increasing of a role of executive bodies and their leaders - «bosses»; improvement of inner-party discipline. Ostrogorski also gave an interesting review of social and psychological streaks of the American electorate and the methods of manipulation the will of voting public practiced by «bosses» [11].

It should be noted that practically along with the publication of paper of Ostrogorski there was published the book of the English political thinker J. Bryce «The American Commonwealth» (1888), and the considerable part of this book was devoted to the analysis of the US party system [12].

The comparison of conclusions concerning this phenomenon done by J. Bryce and M. Ostrogorski gives us right to reckon these researchers among the founders of the modern theory of political parties.

However, unlike the three-volume monograph of Bryce which became straightway worldwide known, Ostrogorski's book, small on volume, did not draw at that time great attention. Ostrogorski could hold himself out in scientific community as one of leaders in development of the political parties theory only after publishing of the monograph «Democracy and the Organization of Political Parties» (1902) [10].

A significant trend in Moisey Ostrogorski's research project was the positivist methodology. The methods used by Ostrogorski to collect primary information also corresponded to the positivist methodology. He practiced the method of observation (taking part in party forums, election rallies, and visiting polling stations), expert surveys, interviewing voters, and analyzing documents. The geography of scientific expeditions of the Russian scientist was very wide. He visited all major regions of the UK, and in the US he researched several states in the East and Midwest.

We believe that in terms of the range of methods used to collect primary information and the geography of research carried out, Moisey Ostrogorski was unparalleled among 
Russian liberal thinkers who participated in the development of the theory of political parties.

Ostrogorski carried out the analysis of functioning of institute of political parties in the democratic political systems of the USA and the UK mainly in the Mill' rationalist paradigm. The starting point of this analysis was the positioning of one's ideal of political structure, with which the results of the political parties' activities were to be compared. At the same time, as it seemed to Ostrogorski, this ideal was to synthesize, in Hegelian terms, the best aspects of the liberal-aristocratic political regime and the achievements of modern democratic systems. The attributive features of this political ideal, as the theorist believed, were as follows: 1) the key role in the political process of the intellectual elite that meets the highest moral requirements; 2) the rational nature of management decisions, provided by the freedom of political leaders from the pressure of party groups, business circles, «crowds», etc.; 3) priority of public interests over private and group interests in the course of making management decisions. Thus, Ostrogorski's political ideal correlated with the liberal paradigm of «rationalistic individualism», which assumed the creation of conditions for strengthening the intellectual component of personal and group activity.

Ostrogorski believed that by the beginning of the $20^{\text {th }}$ century, the process of blurring the ideological political identity of traditional American and English parties was mostly complete. This process was caused by the exhaustion of significant social problems in the United States after the Civil War and in Great Britain after the abolition of the protectionist Corn Laws (1846). This point of view, as shown by political practice, was not quite correct, representing an excessive emphasis on the actual existing trend; as for the phenomenon of the formation and growth of the political influence of social-democratic parties, Ostrogorski could not give any satisfactory explanation for it at all. This did not prevent him, however, from concluding about the loss of the meaning of their existence by the parties, in favor of which, as the scientist believed, the phenomenon of dehumanization of internal party relations also testified.

Ostrogorski noted that the party elites, to compensate for the weakening of the ideological foundations of solidarity among party members, bet on the development of centralization in the leadership of party organizations, tightening internal party discipline and combating dissent, and planting the cult of party leaders. The theorist described internal party relations as a «corporation», a «low form of solidarity», and an «external uniformity» that only masked «opposable» individuals. At the same time, Ostrogorski emphasized, the position of the individual in the party is one of the manifestations of the crisis of an individualistic, «emancipated» type of personality that is being replaced by a «weakened» type of personality, whose features are social passivity, conformity, susceptibility to political and psychological manipulation, and a narrow horizon of political consciousness. These observations of Ostrogorski allow us to consider him as one of the earliest representatives of the liberal-critical trend in the sociology of «mass society».

Long before Robert Michels, Ostrogorski revealed a tendency to «oligarchize» the party leadership, to get it out of the control of ordinary members, and to turn parties into the tools for implementing the group interests of the party elites in power structures. He analyzed in detail the internal party mechanism of power, based on the ability of a narrow governing party center to manipulate personnel, information, and material resources. The authoritarian style of activity of the party center, the theorist believed, is paradoxically largely due to its «public organization», that is, to the formally democratic (elective) principles of its formation, giving it a reason to pretend to be the only and legitimate representative of the party.

A distinctive feature of Ostrogorski's work was the extensive use of the elements of functional analysis of the political system. He tried to find the answer to the question to what extent political parties had solved the problems posed by the mass political process - 
the problems of articulation and aggregation of interests of the enlarged electorate, instilling in the citizens the norms and skills of a democratic political culture, and adjusting all the parts of the state mechanism. The scientist did not deny some positive results of the activities of mass parties (awakening the interest of the masses in political life, broadcasting to them the basic information about the current political situation, the upward social mobility of the most developed elements of the lower class through the mechanism of party organization, etc.), considering them, however, only insignificant «moments» in the process of formation and development of parties, while the dysfunctional consequences of the party «machine», in his opinion, were much more serious. As one of the main reasons for this, he considered the epistemological feature of the electoral process, which consists in the inability of the mass voter's consciousness to adequately perceive the complex, multi-purpose election programs of the parties. In this situation, the will of citizens inevitably is of a largely conditional, random character, being conditioned not by rational individual choice, but by the influence of manipulative party propaganda («voter hypnosis»). The voter, as a rule, gives a vote of confidence not to the entire party program, but only to its individual items, so the votes collected by the party represent the «sum of several minorities». Protest voting has become common; the outcome of elections is often decided by the «minor intermediate groups» that do not have stable party preferences. Based on this, Ostrogorski believed that the intermediary role of party organizations in relations between state bodies and the electorate does not in fact lead to the formation of skills for rational political participation of voters, only to a very small extent contributes to the expression of significant political interests of citizens and calls into question the representative nature of state institutions in general. With his analysis of this problem, Ostrogorski contributed to the formation of political psychology, outlining the approaches to elucidating a number of patterns of preelection propaganda and the formation of mass political consciousness of voters [10].

\subsection{P. Miliukov}

P.N. Miliukov was one of the first contributors to the present-day theory of political parties, who offered - from the standpoint of positivism - an in-depth analysis of the party system, typical for the authoritarian political regime. After he had witnessed the crown's attempts to design versatile models of «the party of power» in 1906 - 1917, he identified and systematized several essential features typical for this phenomenon. P.N. Miliukov made a correct forecast by stating that the activity, performed by «the party of power», was a most important factor that destroyed the legitimacy of the legislative branch, and it could cause eventual political crises impossible to control. This prediction was confirmed after the February revolution of 1917 [13].

In exile, Miliukov studied the socio-political foundations of the totalitarian regime established in Soviet Russia. He viewed the Communist party as one of the three main pillars of Soviet power (along with the army and the security service) - and the first in importance. He carried out a comprehensive analysis of this phenomenon, examining in detail the organizational structure of the party, its doctrinal foundations, social functions, and social composition $[14 ; 15]$. It is noteworthy that P. N. Miliukov was one of the first to raise the question of the party's governing core as a special class, which much later received further development in the works of M. Gilas [16], M. Voslensky [17], and others. In combination with P. N. Miliukov's research on other aspects of the Soviet state and Soviet society, his analysis of the structure and functioning of the Communist party makes this scientist one of the pioneers of the modern theory of totalitarianism. 
Table 2. Comparative review of the conceptual positions of Russian liberal thinkers on the basic problems of the theory of political parties.

\begin{tabular}{|c|c|c|c|c|c|}
\hline \multirow[b]{2}{*}{ 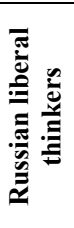 } & \multicolumn{5}{|c|}{ The basic problems of the theory of political parties } \\
\hline & $\begin{array}{l}\text { The problem of } \\
\text { the right of polit- } \\
\text { ical parties to } \\
\text { exist }\end{array}$ & $\begin{array}{l}\text { The desira- } \\
\text { ble social } \\
\text { nature of } \\
\text { parties }\end{array}$ & $\begin{array}{l}\text { Nature of in- } \\
\text { ternal party } \\
\text { relations }\end{array}$ & $\begin{array}{l}\text { The role of political } \\
\text { parties in the political } \\
\text { system }\end{array}$ & $\begin{array}{l}\text { Prospects } \\
\text { for the evo- } \\
\text { lution of the } \\
\text { institute of } \\
\text { political } \\
\text { parties }\end{array}$ \\
\hline 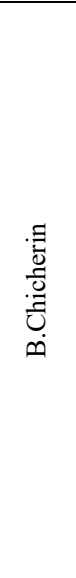 & $\begin{array}{l}\text { Parties are the } \\
\text { second most im- } \\
\text { portant political } \\
\text { institution after } \\
\text { the state; they } \\
\text { mediate the rela- } \\
\text { tionship between } \\
\text { the «organic» and } \\
\text { «inorganic» sub- } \\
\text { systems of the } \\
\text { social system }\end{array}$ & $\begin{array}{l}\text { The domi- } \\
\text { nance of } \\
\text { aristocratic } \\
\text { elements in } \\
\text { the leadership } \\
\text { of all major } \\
\text { parties }\end{array}$ & $\begin{array}{l}\text { The class of } \\
\text { «professional } \\
\text { politicians» } \\
\text { seeks to turn } \\
\text { parties into a } \\
\text { means of profit } \\
\text { and a mecha- } \\
\text { nism for manip- } \\
\text { ulating the } \\
\text { behavior of } \\
\text { ordinary party } \\
\text { members }\end{array}$ & $\begin{array}{l}\text { Main social functions of } \\
\text { the institute of political } \\
\text { parties in democratic } \\
\text { societies are representa- } \\
\text { tive (expression of the } \\
\text { interests of certain social } \\
\text { groups), program- } \\
\text { ideological, organiza- } \\
\text { tional, function of re- } \\
\text { cruiting political leaders, } \\
\text { conducting parliamen- } \\
\text { tary struggle, and exer- } \\
\text { cising state power. Hy- } \\
\text { pothesis about the key } \\
\text { role of a left-wing radi- } \\
\text { cal party in the virtual } \\
\text { political system of the } \\
\text { totalitarian type. }\end{array}$ & $\begin{array}{l}\text { Parties are an } \\
\text { attributive } \\
\text { component of } \\
\text { democratic } \\
\text { political } \\
\text { systems }\end{array}$ \\
\hline 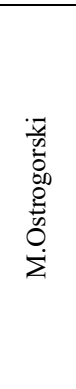 & $\begin{array}{l}\text { Parties have lost } \\
\text { the meaning of } \\
\text { their existence due } \\
\text { to the elimination } \\
\text { of significant } \\
\text { social problems } \\
\text { and contradictions }\end{array}$ & $\begin{array}{l}\text { Conclusion } \\
\text { about the } \\
\text { degradation } \\
\text { of all parties, } \\
\text { regardless of } \\
\text { their social } \\
\text { nature }\end{array}$ & $\begin{array}{l}\text { «Corporation», } \\
\text { a «low form of } \\
\text { solidarity», and } \\
\text { an «external } \\
\text { uniformity» that } \\
\text { only masks } \\
\text { «opposable» } \\
\text { individuals }\end{array}$ & $\begin{array}{l}\text { The institute of political } \\
\text { parties undermines the } \\
\text { principle of separation of } \\
\text { powers and prevents } \\
\text { adequate expression of } \\
\text { the will of the popula- } \\
\text { tion; it has caused a } \\
\text { systemic crisis of demo- } \\
\text { cratic political systems }\end{array}$ & $\begin{array}{l}\text { Parties } \\
\text { should be } \\
\text { forced out of } \\
\text { the political } \\
\text { sphere; they } \\
\text { should be } \\
\text { replaced by } \\
\text { temporary, } \\
\text { highly spe- } \\
\text { cialized } \\
\text { interest } \\
\text { groups }\end{array}$ \\
\hline 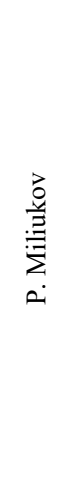 & $\begin{array}{l}\text { The institute of } \\
\text { political parties } \\
\text { optimizes the } \\
\text { transition from } \\
\text { authoritarianism } \\
\text { to democracy; in } \\
\text { democratic socie- } \\
\text { ties, parties con- } \\
\text { tribute to the } \\
\text { rational expres- } \\
\text { sion of the will of } \\
\text { the population and } \\
\text { effectively control } \\
\text { the activities of } \\
\text { state bodies }\end{array}$ & $\begin{array}{l}\text { The Russian } \\
\text { liberal party } \\
\text { must become } \\
\text { the repre- } \\
\text { sentative of } \\
\text { the interests } \\
\text { of the entire } \\
\text { people }\end{array}$ & $\begin{array}{l}\text { In democratic } \\
\text { societies parties } \\
\text { contribute to the } \\
\text { intellectual and } \\
\text { moral develop- } \\
\text { ment of their } \\
\text { members; in } \\
\text { totalitarian } \\
\text { society the party } \\
\text { elite becomes a } \\
\text { special ruling } \\
\text { class }\end{array}$ & $\begin{array}{l}\text { In democratic societies } \\
\text { parties mediate between } \\
\text { civil society and the } \\
\text { state; «parties in power» } \\
\text { play a destructive role in } \\
\text { authoritarian political } \\
\text { systems; the Communist } \\
\text { party is one of the three } \\
\text { main pillars of the Soviet } \\
\text { totalitarian system } \\
\text { (along with the army and } \\
\text { the security service) - } \\
\text { and the first in im- } \\
\text { portance }\end{array}$ & $\begin{array}{l}\text { The role of } \\
\text { parties is } \\
\text { diminishing } \\
\text { in developed } \\
\text { democracies }\end{array}$ \\
\hline
\end{tabular}

\section{Discussion}

Speaking with scientific reports on the subject, the author received recommendations from his colleagues to explore deeper the system of ideological communication and mutual influence within the Russian liberal scientific community. In addition, colleagues advised the 
author to formulate more clearly the criteria for the originality of a particular concept in the field of science about political parties.

The author considers these recommendations worthy of attention and will try to take them into account in his further work on this topic.

\section{Conclusions}

The Russian liberal theory of political parties went through three stages in its development. In the first of them (1858 - 1889), the efforts of Boris Chicherin and Moisey Ostrogorsky made the transition from the early theory of political parties to the modern one, and their research was mainly conducted on the Western material. In the second stage $(1889$ - 1917), the study of domestic political parties and the national party system became an urgent task, especially since 1905 . At the same time, the ideologists of Russian liberalism tracked the latest trends in the development of political parties in the West and predicted the evolution of the Russian party system in the direction of the western models. At the third stage (1917 - 1930s), the works by the Russian liberal theorists reflected various aspects of the confrontation between the Communist party and anti-Communist partypolitical structures, as well as the role and place of the Communist party in the emerging totalitarian system of «dictatorship of the proletariat».

Comparing the history of the development of the Russian liberal theory of political parties from the 1850 s to the 1930 s with the evolution of the world theory of political parties, we can say that it was consistent with the institutional stage of the latter.

One of the specific features of the Russian liberal theory of political parties in the second half of the $19^{\text {th }}$ - first decades of the $20^{\text {th }}$ century was the interest to the entire spectrum of party systems. Even in this regard, the community of the Russian liberal theorists occupied a remarkable, perhaps even unique position in the world political science.

Russian liberal theorists could adhere to various philosophical directions - objective idealism (in its Hegelian interpretation), positivism, and neo-Kantianism, up to including certain components of Marxism in their methodological tools. At the same time, the philosophical views of the liberal theorists used to be synthetic, manifested in the «completion» of the dominant philosophical direction in the system of their representations by other philosophical concepts performing auxiliary heuristic roles. One of the leading motives that prompted the «new» Russian liberals to «synthesize» the latest Western European and domestic achievements in philosophy and political theory was their desire to move from a narrow «party» systems to creating open models of social reconstruction with the participation of the representatives from various scientific schools.

However, this theoretical and methodological syncretism sometimes became an obstacle to the adequate perception of the Russian liberals' concepts by Western political scientists, who had been used to thinking within the framework of more «monistic» paradigms. Thus, the concept of Moisey Ostrogorski was denied a scientific status by some of the Western researchers based on the sharp discrepancy between the positivist methodology of its critical-analytical section and the value-utopian nature of the Russian theorists' ideas about the ways of transition to a «non-partisan» political space.

The author believes, the search for the philosophical bases of liberal ideology is legitimate - though not at the general philosophical level, but the level of political philosophy. In the scientific literature, such concepts of political philosophy as the principle of free human will, the theory of self-organizing society, the concept of the legal reason, the concept of the legal state, the recognition of the priority of legality over politics, and others have been identified. All these concepts, especially their modernization and development as part of the Russian «new» liberalism have had a significant impact on the development of the Russian liberal theory of political parties, along with other factors, such as the historical experience 
of the political development of the West, the achievements of the Western political thought, and the current political situation in Russia. First of all, we are talking about the theory of political parties related to the justification of conditionality of political pluralism (private manifestation of which is the multi-party system) by the laws of social evolution, the justification of the principle of legality of political parties' activities with a reformist orientation and focused on the search for cross-party compromise based on the priority of public interests, the determination of the conditions of humanization of interpersonal relationships in political communities. The development of the Russian liberal theory of political parties had also been affected by the perspective of historical philosophy, traditional for the Russian social thought, addressing the issues related to the specifics of the Russian historical process and the relations between Russia and the West and also having an impact, in particular, on the formation of the concept of liberal «non-class» party and on the assessment of the prospects of the Russian party system's evolution.

Socio-philosophical aspects of the theory of political parties should be considered in the context of the main problems of the political philosophy of Russian liberalism - the problem of clarity of vision, the conditions and characteristics of formation of the Russian constitutional legal state system designed to ensure the implementation and protection of the individual's rights from all the forms of political tyranny, including the tyranny from the majority of society («unlimited democracy»). Therefore, in terms of content, the social and philosophical problems of the Russian liberal theory of political parties included three thematic units. The first of them was intended to answer the question of the extent to which the inclusion of political parties in the public life has affected the West and, therefore, should further affect the nature of constitutional and legal statehood in Russia, the attributes of which have traditionally been considered the separation of powers, parliamentarism, and the priority of law. The second thematic unit was related to the interpretation of the individual's place and role within the party structures (to what extent, for example, an individual can make and implement free, rational political decisions under the psychological and organizational influence of the authoritative party elites, the majority of party associates, etc.). And finally, the third group of themes raised the issue of the socio-historical conditions of formation and development of institute of political parties, the issue of the extent of its ability to adequately represent this policy-relevant interests of certain social groups, as well as the fundamental issue of social, political and moral condition of the party's right as part of society to define the trajectory of the society's development in general.

All the Russian liberal theorists agreed in recognizing the modernization processes as the most common reason for the establishment of the institution of the modern mass political parties. The phenomena of disappearance of the class division of society and other traditional forms of social organization associated with the modernization, accompanied by an increase in alienation, dehumanization, and depersonalization of public relations, dictated the need for new forms able to restore the individual's lost sense of community with other people and to help him articulate and realize his social interests arising from his changed social class status. Political parties have become one of these forms.

However, within the framework of the Russian liberal party science, two main trends have been identified in the near-term historical perspective based on the denial or recognition of the right to exist for the institution of political parties. The first of them, presented mainly only by Moisey Ostrogorski (although in some periods similar views could be expressed by other theorists, for example, Evgeniy Trubetskoy), postulated the exhaustion of positive potential of the institute of political parties by the beginning of the $20^{\text {th }}$ century. The second direction, which was joined by the vast majority of liberal researchers, considered political parties as a relatively new institution that is still emerging and has not fully revealed its capabilities, which should establish itself in the political space of Russia and further become an attributive component of the constitutional and legal system. In the most 
general sense, the institution of political parties was seen by the majority of the Russian liberal theorists as an intermediary link in the relationship between the state and society. They were convinced of the indispensability of parties as the newest and most effective mechanism at the present stage for transforming the spontaneous actions of the masses into socially expedient acts, as a link in the system of relations between state bodies, ensuring the integrity of the state apparatus and thus its ability to effectively regulate the processes of social development. Critics of Ostrogorski and similar supporters of the «non-partisan» political space stated the individual's ability to progressively perceive complex party programs as a function of his participation in the process of maturing and developing a «collective thought», as well as in the course of practical political activity (P. Miliukov). Thus, they emphasized the humanistic aspect of party activity, which is manifested in the development of moral, intellectual, communicative and volitional qualities of the individual party members.

While noting the fundamental differences between these two approaches, it should also be noted that their representatives were ready to consider each other's most convincing arguments and to develop compromise approaches. So, Moisey Ostrogorski deemed it possible to implement not one but several goals by highly specialized interest groups, which brought this organizational form closer to the model of a political party. Many supporters of the institution of political parties recognized that it was inappropriate to give parties a narrow class character and introduce strict internal party discipline. Moisey Ostrogorski the same as some of his critics (for example, Pavel Miliukov), based on their vision of trends in the development of the social sphere, formulated a conclusion about the historicity of the institution of political parties, the inevitability of its death (or, at least, qualitative transformation) in the conditions of minimizing social class contradictions and the formation of developed democracy.

The theoretical constructions of Russian liberals in the field of political party theory had a pronounced applied orientation. Most of these theorists thought of an effective liberal party in Russia - a key component of the domestic party system - only as a social-liberal one. This project was not implemented for some reasons, which partially caused the defeat of the constitutional democrats in the confrontation with the «new type» Communist party. We believe that the idea of social liberalism is also relevant in the context of modern Russian political realities.

\section{References}

1. G.M. Hamburg, Boris Chicherin and Early Russian Liberalism, 1828-1866 (1992)

2. P. Pombeni, Hist. J., 37(2), 319-341 (1994)

3. G. Quagliariello, Politics without Parties. Moisei Ostrogorski and the Debate on Political Parties on the Eve of the Twentieth Century (1996)

4. M.K. Stockdale, Paul Miliukov and the Quest for a Liberal Russia, 1880-1918 (1996)

5. B. Chicherin, Liberty, Equality and the Market (1998)

6. K.A. Wittfogel, Oriental Despotism: A Comparative Study of Total Power (1981)

7. B.J. Moore-Gilbert, Postcolonial Theory: Contexts, Practices, Politics (1997)

8. H. Arendt, The Origins of Totalitarianism (1951)

9. C.J. Friedrich, Z. Brzezinski, Totalitarian Dictatorship and Autocracy (1961)

10. M. Ostrogorski, Democracy and the Organization of Political Parties (1902)

11. M. Ostrogorski, De l'organisation des partis politiques aux Etats-Unis (1889)

12. J. Bryce, The American Commonwealth (1888) 
13. P. Miliukov, Political memoirs 1905-1917 (1967)

14. P. Miliukov, Bolshevism: an International Danger: its Doctrine and its Practice through War and Revolution (1920)

15. P. Miliukov, Russia Today and Tomorrow (1922)

16. M. Djilas, New Class (1961)

17. M. Voslensky, Nomenklatura: Anatomy of the Soviet Ruling Class (1984) 